\title{
International Criminal Judiciary Decisions: Is It A Source of International Criminal Law?
}

\author{
Dr. Omar Mahmoud Amar \\ Associate Professor of International Law, Faculty of Law- Applied Science Private University, Amman - Jordan
}

\begin{abstract}
The Sources of international criminal law are very important because they drive us to international and revelation of criminal texts, and because they are related to the principle of legality. In addition, international criminal judiciary decisions played significant part in development of this law, in spite of legal controversy over consideration of those decisions as source of international criminal law, particularly because Rome Statutes of International Criminal Court didn't refer to consideration of those decisions as a source that International Criminal Court can reference.
\end{abstract}

Keywords: International Criminal Court, International Criminal Law, International Judiciary Decisions.

DOI: $10.7176 / \mathrm{JLPG} / 86-11$

Publication date:June $30^{\text {th }} 2019$

\section{Introduction:}

International Criminal Law is a set of legal rules that define the acts that constitute international crimes, define the penalties prescribed for them and the measures that shall be followed when such crimes are committed to enable imposition of punishment on whoever is liable for them ${ }^{1}$.

This law is a branch of public international law. However, because of its modernity, it is technically related to domestic criminal law and derives from it bases- after customization thereof- to build its decisions to grow till it becomes stable ${ }^{2}$. What results from International Criminal Law being a branch of public international law is that its sources are the same as those of the latter ${ }^{3}$.

The Sources of public international law are mentioned in article 38 of the statute of International Court of Justice which stipulates that:

(1. The Court, whose function is to decide in accordance with international law such disputes as are submitted to it, shall apply:

a. international conventions, whether general or particular, establishing rules expressly recognized by the contesting states;

b. international custom, as evidence of a general practice accepted as law;

c. the general principles of law recognized by civilized nations;

d. subject to the provisions of Article 59, judicial decisions and the teachings of the most highly qualified publicists of the various nations, as subsidiary means for the determination of rules of law.

2. This provision shall not prejudice the power of the Court to decide a case ex aequo et bono, if the parties agree thereto)

Ad hoc tribunals that preceded International Criminal Court applied the provision of article 38 of the statute of The International Court of Justice ${ }^{4}$. This is proved by the fact that all statutes of Ad hoc tribunals (Nuremburg, Tokyo, Former Yugoslavia and Rwanda) didn't stipulate any sources of international criminal law.

Concerning the Rome Statute of International Criminal Court, the preparatory committee on establishment of International Criminal Court understood, from the beginning of its works, the importance of reference to applied law in the statute of the new court, because of its particular importance, particularly lack of acceptable codification of international criminal law, which was one of the pillars on which those who opposed establishment of the international criminal court relied over long years ${ }^{5}$.

Sources of international criminal law were actually stipulated in article 21 of Rome Statute, which was similar- not identical- to article 38 of Statute of the International Court of Justice ${ }^{6}$. Article 21 of Rome Statute stipulates that:

\footnotetext{
${ }^{1}$ Mahmoud Naguib Hosni, Lessons in Criminal Law, Dar al-Nahda al-Arabiya, Cairo, 1959/1960, p. 7.

${ }^{2}$ Ali Abdel Qader Al-Kahwaji, International Criminal Law, Halabi Human Rights Publications, Beirut, 2001, p. 5

${ }^{3}$ ROBERT CRYER, HA KAN FRIMAN, DARRYL ROBINSON, and ELIZABETH WILMSHURST, AN INTRODUCTION TO INTERNATIONAL CRIMINAL LAW AND PROCEDURE, Cambridge University Press, New York 2007, p.6.

${ }^{4} \mathrm{I}$ have noted this after the judgments of the International Criminal Tribunal for the former Yugoslavia, for example:

Aleksovski (IT-95-14/1(, Appeal Chamber Judgment ,24 March 2000, fn.364.

${ }^{5}$ Leila Nadya Sadat, The ICC and The Transformation Of International Law, Transnational Publishers, INC, 2002, p.173.

${ }^{6}$ Sawsan Tamr Khan Bekha, Crimes Against Humanity, Halabi Human Rights Publications, Beirut 2006, p. 127; ROBERT CRYER and Others, op.cit. p.6.
} 


\section{(1. The Court shall apply:}

(a) In the first place, this Statute, Elements of Crimes and its Rules of Procedure and Evidence;

(b) In the second place, where appropriate, applicable treaties and the principles and rules of international law, including the established principles of the international law of armed conflict;

(c) Failing that, general principles of law derived by the Court from national laws of legal systems of the world including, as appropriate, the national laws of States that would normally exercise jurisdiction over the crime, provided that those principles are not inconsistent with this Statute and with international law and internationally recognized norms and standards.

2. The Court may apply principles and rules of law as interpreted in its previous decisions.

3. The application and interpretation of law pursuant to this article must be consistent with internationally recognized human rights, and be without any adverse distinction founded on grounds such as gender as defined in article 7, paragraph 3, age, race, colour, language, religion or belief, political or other opinion, national, ethnic or social origin, wealth, birth or other status).

Concerning similarity between the provision of article 21 of Rome Statute and article 38 of the statute of International Court of Justice, some jurisprudence stated that article 21 of Rome Statutes defines the law that shall be applied by the court, which is accordingly not considered specification of the sources of international criminal law, but its role is largely similar to the role of article 38 of the Statute of International Criminal Court for international law in general ${ }^{1}$.

In this topic, the following question may be raised: Is the provision of article 21 of Rome Statute related to applicable law sufficient, and there is no necessity to refer to the provision of article 38 of Statute of International Court of Justice?

Some writers believe that article 21 of Rome Statutes didn't provide us with answers to many ambiguous matters that may appear by the court, so the Court Judges will be forced to look for solutions of those matters in another position, which they will find in article 38 of the statute of International Court of Justice that will provide them with general answers for resolution of any problem ${ }^{2}$.

In fact, this is a logical result. In application of the provision of article 21 of Rome Statute, paragraph (B) of article 21/1 of Rome Statute stated that Court shall apply (Principles and Rules of International Law) and sources of public international law which are stipulated by in article 38 of the statute of International Court of Justice, so it had to reference them ${ }^{3}$.

In view of the foregoing, is it possible to reference the rulings of international criminal judiciary in accordance with article 38 of the statute of International Court of Justice and to consider these judgments to be source of international criminal law?

Analysis and discussion shall define the meaning of decisions of international criminal judiciary.

\section{Determination of International Criminal Judiciary Decisions}

International criminal judiciary decisions are those judicial decisions which are issued by international criminal courts, not only decisions made by International Criminal Court, but also decisions made by other international criminal courts. Therefore, judicial decisions issued by national courts are outside the matter of the research because, even if they have role in building the provisions of international criminal law, their role is not direct ${ }^{4}$.

In addition, we exclude from the field of this research decisions of non-criminal international courts, such as the International Court of Justice and decisions of arbitration courts while they in fact play important role in development of the rules of public international law.

We also exclude the decisions made by courts that don't have international standing, even if they are related to international crimes, such as the courts established in accordance with law No (10) of Germany Supervisory Council, due to their articular nature that can't be described as international courts, although their decisions played key role in clarification of sides of definition of crimes against humanity, and they were largely adopted in jurisprudence of international criminal law. They also played considerable role in some issues that were considered before The International Criminal Tribunal for the former Yugoslavia (ICTY) as in Tadic Case ${ }^{5}$.

Finally, concerning the matter of this research, decisions made by hybrid courts or the so-called international domestic tribunals which are courts that combine statutes and bylaws established by the United

\footnotetext{
${ }^{1}$ Mohamed Safi Yousef, The General Framework of International Criminal Law in the Light of the Statute of the International Criminal Court, Dar al-Nahda al-Arabiya, Cairo, 2002, p. 113.

${ }^{2}$ William A. Schabas, An Introduction To The International Criminal Court, Second Edition, Cambridge University Press, New York 2004, P.90 - P.91.

${ }^{3}$ Hamza abu issa, The Compatibility of the Rules of Evidence before the International Criminal Court with the Theory of Criminal Evidence, Amman 2012, p.27.

${ }^{4}$ ANDRÉ NOLLKAEMPER, Decisions of National Courts as Sources of International Law, in: Gideon Boas \& William A .Schabas (editors), INTERNATIONAL CRIMINAL LAW DEVELOPMENTS IN THE CASE LAW OF THE ICTY, Brill Academic Publishers, Netherlands 2003, p.277.

${ }^{5}$ Sawsan Tamr Khan Bekha, op. cit, P.58.
} 
Nations; that is, they combine the advantages of interim courts and subsequent advantages before national courts $^{1}$, such as the court that was established in East Timor Tribunal and Sierra Leone Tribunal.

Therefore, this study will be limited decisions of International Criminal Court (ICC) and the following international criminal courts: The Nuremberg trials, the Tokyo Trial, The International Criminal Tribunal for the former Yugoslavia (ICTY) and The International Criminal Tribunal for Rwanda (ICTR).

\subsection{The Nuremburg and Tokyo Trials Decisions:}

There is no doubt that Nuremburg Tribunal (1945) is the first international criminal court, and it was followed in creation by Tokyo Tribunal (1946). In spite of the broad criticisms to those tribunals, we can't deny their role in development of the idea of criminal judiciary and turning it from theoretical field to applied field.

Through those trials, several legal and realistic matters related to international criminal law were raised, so their judgments opened room for many researches.

It is proved that when Nuremburg Tribunal was established there were no codified rules of international criminal law, so when this court tried to detect those rules by reading the international custom and conventions and concluding the fundamental principles on which rules of international law are based, ruling of this court expressed- within the facts that were referred thereto- the rules of international law ${ }^{2}$.

Due to importance of the principles derived from Nuremburg Tribunal, UN General Assembly adopted, on $11 / 12 / 1946$, resolution in which it confirmed that codification of legal principles that were revealed by Nuremburg Tribunal and formed them as clear and specific rules will contribute to progress of international criminal law and confirmation of its judgments.

In decision No 177 dated 21/10/1947, General Assembly assigned international law committee to the duty of work on drafting those principles. The committee has actually completed its work and drafted the principles derived from Nuremburg Tribunal. However, the report that was submitted by the committee wasn't attested by the countries at the time ${ }^{3}$. Principles recorded by the committee are important. Dr.Mahmoud Naguib Hosny states that, "Principles contained in the report are very important. They contained authentication of the rules established by Nuremburg Tribunal. It is possible that those principles are considered nuclei of international penal code. It is noted that the committee didn't target by those principles to set full-fledged penal code. Its duty was limited to clarification of pillars of international criminal law, and can conclude this from Nuremburg Tribunal Judiciary" 4.

We don't believe that decisions of Nuremburg and Tokyo Tribunals are source of international criminal law at present, because the principles derived from their decisions were codified and stipulated in Rome Statutes, so there is no need to refer to them.

\subsection{Decisions of former Yugoslavia and Rwanda Tribunals:}

Yugoslavia Tribunal considers the International Criminal Court to be the third, after Nuremburg and Tokyo Tribunals. It was established in virtue of Security Council Resolution No 808 on 22/03/1993, and was followed by Rwanda Tribunal that was established in accordance with Security Council Resolution No 955 on 08/11/1994. Decisions of those two Tribunals are very important in development of the rules of public international law and international criminal law. In the field of public international law, those two courts established important customary rules. For example, first instance chamber of Yugoslavia Court noted in its judgment rendered on 10/08/1995 in Tadić case to the rules of international humanitarian law on international armed disputes that apply to non-international armed disputes. In its decision dated 08/03/1996 in Martić Case, the court referred to abstention from revenge acts against civilians as customary rule ${ }^{5}$.

Concerning international criminal law, judgments of those two tribunals reflected determination of the elements of some crimes. In addition, our discretion enriched and developed the law related to sex-based crimes, which is a good beginning for ban of rape, particularly because it was justified at the time of war ${ }^{6}$.

In general, trials of those two tribunals are different from the precedents of World War II in direction of judiciary and prosecution to define the crime and set list of its pillars, which was very effective in progress of discussions in Rome Convention and the subsequent sessions of the ad hoc committee that established detailed elements of each type of sexual violence crimes?

\footnotetext{
${ }^{1}$ Vida Najib Hamad, The International Criminal Court Towards International Justice, Halabi Rights Publications, Beirut 2006, p.29.

${ }^{2}$ Mahmoud Naguib Hosni, op. cit, P45.

${ }^{3}$ Gerhard van Glan, The Law Between Nations, The Arabization of Elie and Reel, Part III, New Horizons House, Beirut, 1970 , p.218 et seq.

${ }^{4}$ Mahmoud Naguib Hosni, op. cit., P.49.

${ }^{5}$ Ghassan El Gendy, Volcanic Aesthetics in the Principles of Public International Law (Sources), Dar Wael, Amman 2005 , p.415.

${ }^{6}$ Sawsan Tamr Khan Bekha, op. cit, p.369.

${ }^{7}$ Ibid., p.371.
} 


\section{Discussion and analysis:}

In accordance with article 38 of the statute of International Court of Justice, decisions of international judiciary shall be secondary source of international law. This recognition of those decisions as source of international law resulted in that they largely contributed to development of rules and principles of international law. Dr. Ghassan Al Gendy rightfully said: "It is not exaggeration to say that expert houses and research departments teach the provisions of international judiciary such as labs study of genetic code of virus by microscope" ${ }^{1}$.

Article 21 of Rome Statute didn't stipulate that decisions of international judiciary be considered source of international criminal law, but it authorized the court to apply principles and rules of law as interpreted in their previous decisions. This means that it is not bound with the interpretations issued thereby, and confirms that Rome Statute didn't take the system of mandatory judicial precedents taken by it in the Anglo-Saxon System, and adopted work of Latin System that previous judicial interpretations are not binding even on the judiciary that issued it, in contrast to what is followed by Yugoslavia and Rwanda tribunals that applied the system of judicial precedents.

Some researchers said that this confirms that judicial precedents system is not part of criminal international law and it is not part of public international $\mathrm{law}^{2}$. However, some writers believe that, based on the fact that the court "may apply" its previous practice, it is probable that it will follow practice of International Court of Justice in this respect, and that it will not hesitate in reference to its previous judgments before all by the Appeal Department to support its new decisions. However, when it decides, in contravention to the new circumstances of the case, it will disclose the legal arguments for not following its previous decisions ${ }^{3}$.

However, what is the matter of judgments of other criminal courts? Can international criminal court reference them?

If we considered practices of The International Criminal Tribunal for the former Yugoslavia, we would find that it often approached judicial decisions to interpret legal matters. The International Criminal Tribunal for the former Yugoslavia and The International Criminal Tribunal for Rwanda referred to many local and international judicial precedents ${ }^{4}$.

In view of Rome Statute, by reference to article 21 thereof, it didn't stipulate that decisions of International Criminal Court are source of law, which urged some to say that so long as article 21 didn't note or refer to judicial precedents of other criminal courts (whether military or ad hoc) at all, this means non-recognition that they constitute "customary law" 5 . In general, judicial precedents of any international court can't contribute to development of customary law, since, in accordance with article 38 (1) (B) of the statutes of International Court of Justice, customary law arises out of set of practices and corresponding opinions of states, so only states are key players that decide the matter of customary law ${ }^{6}$.

However, does this mean that decisions of international criminal courts may not be referenced by the International Criminal Court?

This appeared in two approaches:

First: Decisions of other criminal courts may not be referenced.

This approach is advocated by part of jurists in accordance with the provision of article 21 which authorized that court decisions may be referenced. Therefore, this means that possible revocation is limited to some judgments, which means that other court decisions may not be referenced ${ }^{7}$. One of the preliminary departments of International Criminal Court adopted this approach and warned of automatic application of judicial precedents of $A d$ hoc tribunals. Its decision states:

"As to the relevance of the case law of the ad hoc tribunals, the matter must be assessed against the provisions governing the law applicable before the Court. Article 21, paragraph 1, of the Statute mandates the Court to apply its Statute, Elements of Crimes and Rules of Procedure and Evidence 'in the first place' and only 'in the second place' and 'where appropriate', 'applicable treaties and the principles and rules of international law, including the established principles of the international law of armed conflict'. Accordingly, the rules and practice of other jurisdictions, whether national or international, are not as such 'applicable law' before the Court beyond the scope of article 21 of the Statute. More specifically, the law and practice of the ad hoc tribunals, which the Prosecutor refers to, cannot per se form a sufficient basis for importing into the Court's procedural framework

\footnotetext{
${ }^{1}$ Ghassan El Gendy, op. cit, p.5.

${ }^{2}$ FABIAN O. RAIMONDO, General principles of law in the decisions of international criminal courts and tribunals, University of Amsterdam 2007, P.156.

${ }^{3}$ Vladimir-Djuro Degan, On the Sources of International Criminal Law, Chinese Journal of International Law (2005), Vol. 4, No. 1, p.82.

${ }^{4}$ ROBERT CRYER \& others, op. cit, p.12.

${ }^{5}$ Vladimir-Djuro Degan, op. cit, p.82.

${ }^{6}$ PetraViebig, Illicitly Obtained Evidence at the International Criminal Court, Asser Press 2016, P.31.

${ }^{7}$ Youssef Hassan Youssef, International Criminal Law and Sources, National Center for Legal Publications, Cairo, 2010, p.12.
} 
remedies other than those enshrined in the Statute."I

Second approach: Possible reference to international criminal courts decisions:

This approach is adopted by part of jurists, in accordance with the provision of article 38 of statutes of international criminal court, which states that although importance of interim international decisions of customary law are not clear, article $(38 / 1 / \mathrm{d})$ of statutes of International Court of Justice as portal for consideration of judicial precedents of those courts as indirect evidence of customary law. That article provides "Key judgments [...] as an alternative means" for determination of the rules of law". The general methodology derived from it states that judicial decisions are not source of law in themselves; they reflect a rule of international law such as customary rule. Therefore, when an interim international court discovers a rule of customary law, judiciary of international criminal court authorizes use of that as a source for establishment of their legal standing ${ }^{2}$.

In the same context, some say that precedents of international criminal court of former Yugoslavia and international criminal court of Rwanda can be indirectly used on determination of the general principles of law in accordance with articles 21 (1) (C) of statutes of International Criminal Court, although use of those principles is restricted by restrictions similar to those of international customs ${ }^{3}$.

\section{Conclusion}

Determination of the sources of law is an important matter for any branch of law. Whereas criminal international law is a modern branch of public international law, its rules and decisions were established with declaration of statutes of International Criminal Court (Rome Statute) which defined the sources of this law in article 21 thereof. In accordance with this definition, some questions and problems related to sources of international criminal law appeared. Those questions the matter of this research which is indispensable includes answer to important question on possible consideration of decisions of international criminal judiciary as a source of law.

This question didn't raise any problem for judgments of international criminal court. Article 21 of Rome Statute is clear in this respect in that court may adopt the interpretations contained in its previous decisions, which means that court is not bound with its previous decisions, while court is allowed, which is a matter that shall be directly assessed by the court by referring to those decisions.

However, the problem arises in respect of decisions of other international criminal courts. If this matter is decided for the decisions of Nuremburg and Tokyo Tribunals, as the legal principles contained in their decisions codified in the international conventions and agreements, this problem appears for decisions of The International Criminal Tribunal for the former Yugoslavia and The International Criminal Tribunal for Rwanda.

Two approaches appeared her for resolution of this problem: The first opposes approaching decisions of international criminal court and the second believes that it is possible to reference those decisions, even if indirectly.

We believe that it is possible to refer to decisions of international criminal court, even though article 21 of Rome Statute didn't stipulate this, since most of those judgments only reveal international customs and interpret some provisions contained in the conventions.

Therefore, this article had to refer to the court's possible adoption of decisions of international criminal judiciary as a referential not binding source, like article 38 of the statutes of International Court of Justice, particularly because decisions of those courts, particularly courts of Yugoslavia and Rwanda have come to constitute generally acceptable jurisprudence which is cited in all juristic studies related to international criminal law and decision of most dangerous international crimes in particular, and that failure to rely on jurisprudence of those courts will constitute in most cases waste of time of the court in re-investigation of matters on which there were logical solutions that were widely approved by international jurisprudence.

\section{References}

- $\quad$ Ali Abdel Qader Al-Kahwaji, International Criminal Law, Halabi Human Rights Publications, Beirut, 2001.

- ANDRÉ NOLLKAEMPER, Decisions of National Courts as Sources of International Law, in: Gideon Boas \& William A .Schabas (editors), INTERNATIONAL CRIMINAL LAW DEVELOPMENTS IN THE CASE LAW OF THE ICTY, Brill Academic Publishers, Netherlands 2003.

- $\quad$ FABIAN O. RAIMONDO, General principles of law in the decisions of international criminal courts and tribunals, University of Amsterdam 2007.

- Gerhard van Glan, The Law Between Nations, The Arabization of Elie and Reel, Part III, New Horizons House, Beirut, 1970.

\footnotetext{
${ }^{1}$ Situation in Uganda (ICC-02/04-01/05), Decision on the Prosecutor's Position on the Decision of Pre-Trial Chamber II to Redact Factual Descriptions of Crimes from the Warrant of Arrest, Motion for Reconsideration, and Motion for Clarification, 28 October 2005 , para. 19.

${ }^{2}$ Nerlich V, The status of ICTY and ICTR precedence in proceedings before the ICC. In: Stahn C, Sluiter G (eds) The emerging practice of the International Criminal Court. Martinus Nijhoff Publishers, Leiden 2009, p. 313 et seq.

${ }^{3}$ Petra Viebig, op. cit, p.32.
} 
- Ghassan El Gendy, Volcanic Aesthetics in the Principles of Public International Law (Sources), Dar Wael, Amman 2005

- Hamza abu issa, The Compatibility of the Rules of Evidence before the International Criminal Court with the Theory of Criminal Evidence, Amman 2012.

- Leila Nadya Sadat, The ICC and The Transformation Of International Law, Transnational Publishers, INC, 2002.

- Mahmoud Naguib Hosni, Lessons in Criminal Law, Dar al-Nahda al-Arabiya, Cairo, 1959/1960.

- Mohamed Safi Yousef, The General Framework of International Criminal Law in the Light of the Statute of the International Criminal Court, Dar al-Nahda al-Arabiya, Cairo, 2002.

- $\quad$ Nerlich V, The status of ICTY and ICTR precedence in proceedings before the ICC. In: Stahn C, Sluiter G (eds) The emerging practice of the International Criminal Court. Martinus Nijhoff Publishers, Leiden 2009.

- $\quad$ Petra Viebig, Illicitly Obtained Evidence at the International Criminal Court, Asser Press 2016.

- $\quad$ ROBERT CRYER, HA KAN FRIMAN, DARRYL ROBINSON, and ELIZABETH WILMSHURST, AN INTRODUCTION TO INTERNATIONAL CRIMINAL LAW AND PROCEDURE, Cambridge University Press, New York 2007.

- Sawsan Tamr Khan Bekha, Crimes Against Humanity, Halabi Human Rights Publications, Beirut 2006.

- Vida Najib Hamad, The International Criminal Court Towards International Justice, Halabi Rights Publications, Beirut 2006.

- Vladimir-Djuro Degan, On the Sources of International Criminal Law, Chinese Journal of International Law (2005), Vol. 4, No. 1.

- William A. Schabas, An Introduction To The International Criminal Court, Second Edition, Cambridge University Press, New York 2004.

- Youssef Hassan Youssef, International Criminal Law and Sources, National Center for Legal Publications, Cairo, 2010. 